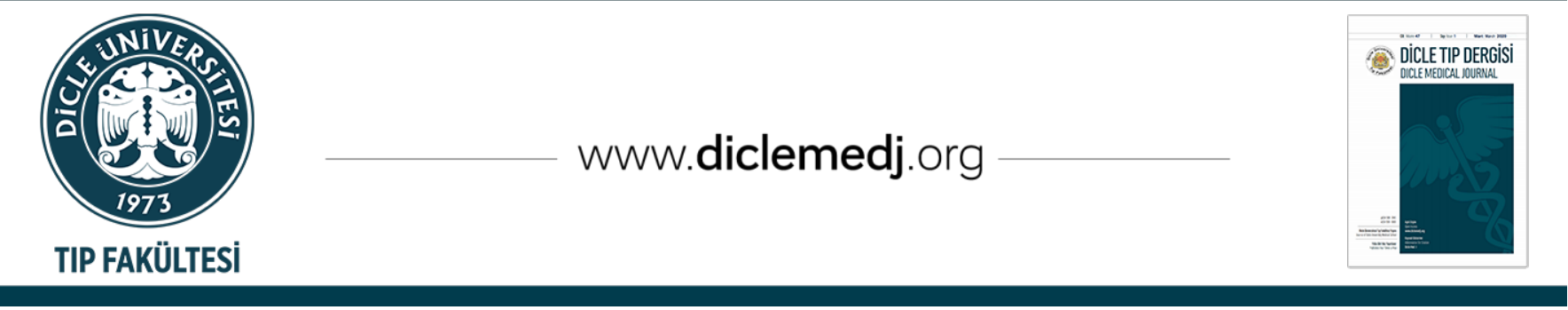

Original Article / Özgün Araştırma

\title{
Investigation of the Association between Bispectral index and Body Temperature during Abdominal Surgery; An Observational Study
}

\author{
Cigdem Akyol Beyoglu ${ }^{D}$, Ceylan Saygili ${ }^{D}$, Mustafa Dilek ${ }^{i}$ 1, Guniz Meyanci Koksal 1 \\ 1 Istanbul University- Cerrahpasa, Cerrahpasa School of Medicine, Dept of Anesthesiology and
} Reanimation, Istanbul, Turkey

Received: 14.05.2020; Revised: 08.09.2020; Accepted: 10.09.2020

\begin{abstract}
Objective: Bispectral index (BIS) is mainly used for drug titration and is well correlated with drug concentration and hypnosis. Our aim was to present the correlation between hypothermia and BIS during abdominal surgery.

Methods: The study was conducted in patients with American Society of Anesthesiologists (ASA) score I-III, aged between 18-60 $\mathrm{y}$, who had undergone abdominal operation in general surgery theatre. Body temperature and BIS scores when awake, after anesthesia induction, after tracheal intubation and every 5 minutes during the operation, and after extubation were measured and recorded.
\end{abstract}

Results: Three hundred patients were included to the study. Repeated measure regression analysis of BIS scores with the body temperature at distinct time points did not show a significant relationship. None of the patients had a body temperature lower than $35^{\circ} \mathrm{C}$.

Conclusions: As a result of our study, we can say that temperature decrease up to $35^{\circ} \mathrm{C}$ may not have an effect on $\mathrm{BIS}$ scores, and BIS maybe used safely to indicate hypnosis level at temperatures $35^{\circ} \mathrm{C}$ and above during abdominal surgery.

Keywords: Abdominal surgery, Body temperature, Bispectral index.

DOI: 10.5798/dicletip.799935

Correspondence / Yazışma Adresi: Cigdem Akyol Beyoglu, Istanbul University- Cerrahpasa, Cerrahpasa School of Medicine, Dept of Anesthesiology and Reanimation, Istanbul, Turkey e- mail: akyolbeyoglu@gmail.com 


\section{Batın Cerrahisinde Bispektral indeks ve Vücut Sıcaklığı arasındaki İlişkinin Araştırılması; Gözlemsel Çalışma}

Öz

Amaç: Bispektral indeks'in (BIS) ilaç konstantrasyonları ve hipnoz ile olan ilişkisi dolayısıyla ilaç titrasyonu için sıklıkla kullanılmaktadır. Amacımız; batın cerrahisinde BIS ile hipotermi arasında bir ilişki olup olmadığını araştırmaktı.

Yöntemler: Çalışma, Amerikan Anestezi Derneği Skoru (ASA) I-III arasında olan, 18-60 yaş arası batın cerrahisi geçiren hastalarda yapıldı. Hastaların vücut sıcaklığı ve BIS skoru uyanık iken, anestezi indüksiyonu sonrası, trakeal entübasyon sonrası ve entübasyondan sonra her 5 dakikada bir olmak üzere ölçüldü ve kaydedildi.

Bulgular: Çalışmaya 300 hasta dahil edildi. Regresyon analizinde BIS ve vücut sıcaklığı arasında anlamlı bir ilişki saptanamadı. Çalışmadaki hiçbir hastanın vücut sıcaklığ $135^{\circ} \mathrm{C}$ 'nin altında ölçülmedi.

Sonuç: Sonuç olarak batın cerrahisinde $35^{\circ} \mathrm{C}$ 'nin üzerindeki vücut sıcaklıklarında BIS, anestezi derinliğini güvenilir bir biçimde gösterebilir.

Anahtar kelimeler: Batın cerrahisi, Vücut sıcaklığı, Bispektral indeks.

\section{INTRODUCTION}

General anesthesia provides unconsciousness, analgesia and motionless during surgery. Awareness is one of the major risks among patients under anesthesia, since motionless is one of the main objective. Most of the anesthesiologists observe clinical signs to avoid awareness. This situation may result to an increased depth of anesthesia which may cause hemodynamic changes ${ }^{1}$.

The bispectral index (BIS) monitor utilizes electroencephalographic (EEG) signals and provides a value. The value of EEG reflects the level of consciousness of the patient. BIS monitor collects EEG signals through its sensors and it analyzes and interprets the data ${ }^{2}$. BIS values range from 0 (deep anesthesia) to 100 (awake). BIS score between 40 to 60 represent adequate depth of anesthesia for any surgery. BIS is mainly used for drug titration and is well correlated with drug concentration and hypnosis $^{2,3}$. Cognitive dysfunction occurs less frequently and memory is well preserved after surgery when BIS is used for drug titration ${ }^{1}$.

Decreased body temperature causes a decrease in BIS value. Matthew et $\mathrm{al}^{4}$ reported a fall in the BIS score of 1.2 units per degree Celsius during cardiopulmonary bypass (CPB). In a previous study $^{5}$, moderate hypothermia was related to a distinct decrease in BIS score. Zieleger et al ${ }^{6}$ reported that deep hypothermia influenced BIS linearly. Almost all studies showing the correlation between temperature and BIS were done during CPB. A deeper hypnosis occurs in case of hypothermia during surgery and may misguide the clinician while doing drug titration.

The primary aim of the current study was to present the correlation between hypothermia and BIS during abdominal surgery. Our second aim was to find a cut-off value of body temperature indicating a safe BIS score range.

\section{METHODS}

The study was conducted in Istanbul UniversityCerrahpasa, Cerrahpasa School of Medicine General Surgery Operating room, after obtaining local Ethical Committee approval and written patient consent. Patients with American Society of Anesthesiologists (ASA) score I-III, aged between 18-60 y, who had undergone any operation in general surgery theatre. The ambient temperature in all the operating rooms is $20-22^{\circ} \mathrm{C}$. BIS score at the time of accidental hypothermia were recorded. Body temperature of the patients measured in pre-anesthesia unit were recorded. Normothermic patients (body 
temperature $\geq 36^{\circ} \mathrm{C}$ ) were taken to the operating room by after inserting a vascular access with $20 \mathrm{G}$ intravenous cannula from the back of the hand. The hypothermic ones $\left(<36^{\circ} \mathrm{C}\right)$ were heated actively (forced-air) and passively (blanket). In the operating rooms, active and passive heating were routinely applied to all study patients. Patients had routine monitoring including ECG, peripheral oxygen saturation (SpO2), noninvasive blood pressure, tympanic and forehead body temperature measurement. After monitoring, a BIS electrode was attached to the forehead. The first measurements were recorded when awake. A standard anesthesia induction was applied to all patients. Patients who need to get out of the standard were excluded from the study. Anesthesia induction was provided by 2 mg of midazolam (Zolamid 15mg / 3ml, Vemilaç, Turkey), $1 \mathrm{mg} / \mathrm{kg}$ fentanyl (Talinat 0,5mg / 10ml, Turkey), 2mg / kg propofol (propofol 1\% Fresenius, Fresenius Kabi, Germany) and $0.6 \mathrm{mg} \mathrm{/} \mathrm{kg}$ rocuronium (Muscuro 50mg / 5ml, Kocak Farma, Turkey). Body temperature, BIS score and hemodynamic parameters (systolic and diastolic blood pressure, heart rate, Sp02) were recorded. Patients with BIS score $<40$ during mask ventilation were intubated endotracheal (ID: $7.5 \mathrm{~mm}$ in women and ID: $8.0 \mathrm{~mm}$ in men). Systolic, diastolic blood pressures, heart rate, Sp02, ETCO2, BIS, forehead and tympanic body temperatures were recorded after intubation and at 5-minute intervals following it. General anesthesia maintenance were provided with $2 \%$ Sevoflurane inhalation anesthetic in $40 \%$ oxygen-air mixture. At the end of the operation, after reversal of neuromuscular blockage by using atropine and neostigmine, patients with BIS score> 80 were extubated. Body temperature, BIS score and hemodynamic parameters of patients were recorded after extubation. Patients with a BIS score of 100 were taken to the recovery unit. Patients with Aldrete score $>9$ were transferred to the service after an average of 60 minutes.

We used Kolmogorov-Smirnov ( $\mathrm{n}>50$ ) and Skewness-Kurtosis tests to check whether the measurements in the study were normally distributed and we used parametric tests since the measurements were normally distributed. Descriptive statistics for continuous variables in our study; average, standard deviation, minimum and maximum; categorical variables are expressed as numbers and percentages. We used the "Friedman's Bidirectional ANOVA (Related-Samples Friedman's Two-Way ANOVA Statistics)" to analyze the changes in the MAP, HR and BIS measurements of the patients over time. We used "Bonferroni-corrected Post-Hoc multiple comparison tests" for binary comparisons between different times. We used "Pearson Correlation Coefficients" to determine the relationship (correlation) between the measurements. The statistical significance level $(\alpha)$ was taken as 5\% in calculations and SPSS (IBM SPSS for Windows, Ver.24) statistical software was used for calculations.

We used $\mathrm{G}^{*}$ Power statistics package program (ver. 3.1.9.4; Foul and Erdfelder, 1998) in order to calculate Power (test power) and Sample Width of the study. When Type-1 error was taken as 5\% and Power (the power of the test) was 95\%, the number of individuals included in the study was calculated as $n=272$ patients (1). We used Random Probability Sampling method for Sample/Patient selection.

\section{RESULTS}

Three hundred patients were included to the study. Demographic data of the study patients is given in Table I.

Table I: Demographic data

\begin{tabular}{|c|c|}
\hline Age (years) & $53,74 \pm 14,40$ \\
\hline Gender (F/M) (n/\%) & $154 / 147(51.2 / 48.8)$ \\
\hline Height $(\mathrm{cm})$ & $162,97 \pm 24,68$ \\
\hline Weight (kg) & $78,34 \pm 16,39$ \\
\hline $\operatorname{ASA}$ n $(1 / 2 / 3)(\%)$ & 77/168/56 (25.6/55.8/18.6) \\
\hline Operation duration (min) & $105,46 \pm 62,29$ \\
\hline
\end{tabular}

Repeated measure regression analysis of BIS scores with the body temperature at distinct time points did not show a significant relationship. Pearson correlation coefficients at distinct time points were strongest at 105th minute of the operation demonstrating a negative correlation (BIS score $39.51 \pm 12.91$ while body temperature $35.53 \pm 0.67^{\circ} \mathrm{C}$, correlation coefficient: $-.195, \mathrm{p}=0.25$ ) (Table II). 
Table II: Relation between BIS scores and temperature

\begin{tabular}{|c|c|c|c|c|c|}
\hline $\begin{array}{l}\text { Time } \\
\text { Point }\end{array}$ & Variable & Mean & SD & $\begin{array}{l}\text { Correlation } \\
\text { Coefficient }\end{array}$ & $\begin{array}{c}\text { p- } \\
\text { value }\end{array}$ \\
\hline \multirow{2}{*}{$\begin{array}{l}\text { Before } \\
\text { induction }\end{array}$} & Temp $\left({ }^{\circ} \mathrm{C}\right)$ & 36,16 & 61 & \multirow{2}{*}{,$- 171^{* *}$} & \multirow{2}{*}{,003 } \\
\hline & BIS Score & 82,84 & 24,96 & & \\
\hline \multirow{3}{*}{ 15th min } & Temp $\left({ }^{\circ} \mathrm{C}\right)$ & 35,66 & 1,81 & \multirow{3}{*}{,- 070} & \multirow{3}{*}{,230 } \\
\hline & & & & & \\
\hline & BIS Score & 41,53 & 9,95 & & \\
\hline \multirow{3}{*}{ 30th min } & Temp $\left({ }^{\circ} \mathrm{C}\right)$ & 35,65 & 63 & \multirow{3}{*}{,006 } & \multirow{3}{*}{,913 } \\
\hline & & & & & \\
\hline & BIS Score & 43,19 & 11,92 & & \\
\hline \multirow{3}{*}{ 45th min } & Temp $\left({ }^{\circ} \mathrm{C}\right)$ & 35,61 & ,64 & \multirow{3}{*}{,037 } & \multirow{3}{*}{,546 } \\
\hline & & & & & \\
\hline & BIS Score & 43,87 & 12,02 & & \\
\hline \multirow{3}{*}{ 60th min } & Temp $\left({ }^{\circ} \mathrm{C}\right)$ & 35,57 & ,64 & \multirow{3}{*}{,- 012} & \multirow{3}{*}{,857 } \\
\hline & & & & & \\
\hline & BIS Score & 46,97 & 16,47 & & \\
\hline \multirow{3}{*}{ 75th min } & Temp $\left({ }^{\circ} \mathrm{C}\right)$ & 35,42 & 2,40 & \multirow{3}{*}{,080 } & \multirow{3}{*}{,282 } \\
\hline & & & & & \\
\hline & BIS Score & 46,12 & 14,22 & & \\
\hline \multirow{3}{*}{ 90th min } & $\operatorname{Temp}\left({ }^{\circ} \mathrm{C}\right)$ & 35,58 & ,63 & \multirow{3}{*}{,060 } & \multirow{3}{*}{,453 } \\
\hline & & & & & \\
\hline & BIS Score & 50,07 & 19,05 & & \\
\hline \multirow{2}{*}{$\begin{array}{l}105 \text { th } \\
\min \end{array}$} & Temp $\left({ }^{\circ} \mathrm{C}\right)$ & 35,53 & ,67 & \multirow{2}{*}{,$- 195^{*}$} & \multirow{2}{*}{,025 } \\
\hline & BIS Score & 39,51 & 12,91 & & \\
\hline \multirow[t]{2}{*}{120 th } & Temp $\left({ }^{\circ} \mathrm{C}\right)$ & 35,63 & 68 & \multirow{2}{*}{-,093 } & \multirow{2}{*}{,352 } \\
\hline & BIS Score & 39,48 & 15,52 & & \\
\hline
\end{tabular}

None of the patients had a body temperature lower than $35^{\circ} \mathrm{C}$ perioperatively.

Friedman's Two-Way ANOVA statistics demonstrated a significant difference in BIS scores at relevant time points $(\mathrm{p}<0.01)$ (Table III).
Table III: Perioperative BIS scores

\begin{tabular}{|c|c|c|c|c|c|}
\hline & Mean & Std. Dev. & Min. & Max. & *p. \\
\hline $\begin{array}{l}\text { Before } \\
\text { induction }\end{array}$ & $83,6538^{a}$ & 24,47260 & 23,00 & 98,00 & \multirow{9}{*}{$<, 001$} \\
\hline 15 th $\min$ & $40,7500^{\mathrm{ab}}$ & 10,16442 & 4,00 & 68,00 & \\
\hline 30 th $\min$ & $42,2404^{\mathrm{ab}}$ & 9,47198 & 23,00 & 64,00 & \\
\hline 45th min & $41,4327^{a b}$ & 7,68148 & 25,00 & 62,00 & \\
\hline 60th min & $39,8365^{\mathrm{ab}}$ & 8,75903 & 3,00 & 62,00 & \\
\hline 75th min & $42,1731^{\mathrm{ab}}$ & 9,47910 & 26,00 & 82,00 & \\
\hline 90th min & $45,7212^{b}$ & 15,40360 & 21,00 & 98,00 & \\
\hline 105th min & $39,7019 c$ & 9,89251 & 25,00 & 83,00 & \\
\hline 120th min & $43,0769 a^{b}$ & 17,31529 & 24,00 & 98,00 & \\
\hline
\end{tabular}

\section{DISCUSSION}

This is the first study investigating the relation between BIS scores and temperature during abdominal surgery in our literature search. However, we could not demonstrate a significant correlation between BIS scores and body temperature.

The result of the current study is not compatible to the previous studies representing a positive correlation between BIS scores and temperature ${ }^{4,5,7}$. Almost all studies researching the relation between BIS score and temperature were carried out during cardiopulmonary bypass surgery (CPB). Body temperature is decreased to moderate hypothermic levels during CPB which is not a matter of a daily practice of any surgery 6 . Studies demonstrating a correlation between BIS scores and temperature were performed under moderate hypothermia $\left(32-34^{\circ} \mathrm{C}\right)^{3,4}$. In our study, the lowest temperature was above $35^{\circ} \mathrm{C}$. This seems 
to be a valid reason for us that why we couldn't find a correlation between BIS scores and temperature.

Drug metabolism decreases during hypothermia 8 . This issue was established clearly for intravenous anesthetics such as benzodiazepines, propofol and opioids ${ }^{9-11}$. The decrease in anesthetic metabolism during hypothermia provides a deeper hypnosis compared to using anesthetics at equal doses during normothermia ${ }^{12}$. A deeper hypnosis causes a decrease in EEG signals ${ }^{2}$. Furthermore, a previous study presented that; the sevoflurane requirement increases with an increase in temperature ${ }^{13}$. In addition, hypothermia contributes a distinct decrease in cerebral metabolism and has an effect on the level of analgesia and hypnosis' ${ }^{14}$. Due to decreased clearance of analgesics during hypothermia, the analgesic level increases providing a preferable analgesia ${ }^{14}$. Hypothermia provides significant decrease in cerebral metabolism, vasomotor responses, and quantitative EEG signals ${ }^{5}$. Hypothermia and hypothermia induced decreased drug metabolism both contributes to a decrease in BIS score. However, the level of temperature decrease in all the previous studies is below $34^{\circ} \mathrm{C}$. This is the probable main reason, why we could not find a correlation between BIS scores and body temperature. Indeed, open or laparoscopic abdominal surgery increases the risk of heat loss ${ }^{15}$. However, a profound hypothermia was not shown any of the previous studies during abdominal surgery ${ }^{15,16}$. As a result of our study, we can say that temperature decrease up to $35^{\circ} \mathrm{C}$ may not have an effect on BIS scores, and BIS maybe used safely to indicate hypnosis level at temperatures $35^{\circ} \mathrm{C}$ and above. A previous study revealed that at normothermic conditions above $36^{\circ} \mathrm{C}$, BIS scores were well correlated to postoperative shivering among orthopedic surgery patients ${ }^{17}$. The authors explained that shivering is well correlated to patients' awareness ${ }^{17}$. As our study, the previous study supports that BIS is well correlated to body temperatures in normothermic limits ${ }^{17}$.

It is not clear that BIS changes represent a change in depth of anesthesia or any change in another mechanism such as neuronal stunning resulting a deeper anesthesia level. A previous metanalysis presented that BIS monitoring may be impacted by type of surgery or anesthesia method but not by temperature change ${ }^{18}$. We are still unaware of how anesthetic agents act at subnormal body temperatures. On the basis of this issue; this study cannot demonstrate that the lower BIS scores reflect a greater depth of hypnosis. We recommend that anesthetists should not adjust their anesthetic practice, based on information suggesting adequate hypnosis derived solely from a BIS score obtained during lower temperatures, until there has been validation of this technology at very low temperatures.

Ethics Committee Approval: The study was conducted in Istanbul University- Cerrahpasa, Cerrahpasa School of Medicine General Surgery Operating room, after obtaining local Ethical Committee approval and written patient consent.

Declaration of Conflicting Interests: The authors declare that they have no conflict of interest.

Financial Disclosure: No financial support was received.

\section{REFERENCES}

1. Honan D, Doherty D, Frizelle H. A comparison of the effects on bispectral index of mild vs. moderate hypothermia during cardiopulmonary bypass. Eur J Anaesthesiol 2006; 23: 385-90.

2. Bashein G, Nessly ML, Bledsoe SW, et al. Electroencephalography during surgery with cardiopulmonary bypass and hypothermia. Anesthesiology 1992; 76: 878-91.

3. Gökahmetoglu G, Tercan E, Bicer C, et al. Comparison of the depth of anesthesia in sevoflurane and halothane 
anesthesia with bispectral index and 95\% spectral edge frequency Dicle Medical Journal 2013; 40: 350-6.

rewarming phase of cardiopulmonary bypass with moderate hypothermia. J Cardiothorac Vasc Anesth 2013; 27: 59-62.

5. Mezrow CK, Midulla PS, Sadeghi AM, et al. Evaluation of cerebral metabolism and quantitative electroencephalography after hypothermic circulatory, arrest and low-flow cardiopulmonary bypass at different temperatures. J Thorac Cardiovasc Surg 1994; 107: 100619.

6. Miyazaki R, Hoka $S$. What is the predictor of the intraoperative body temperature in abdominal surgery? J Anesth 2019; 33: 67-73.

7. Nguyen NT, Fleming NW, Singh A, et al. Evaluation of core temperature during laparoscopic and open gastric bypass. Obes Surg 2001; 11: 570-5.

8. McAllister RG. Effect of hypothermia on drug metabolism; in vitro studies with propranolol and verapamil. Pharmacology 1980; 20: 95-100.

9. Empey PE, Miller TM, Philbrick AH, et al. Mild hypothermia decreases fentanyl and midazolam steadystate clearance in a rat model of cardiac arrest. Crit Care Med 2012; 40: 1221-8.

10. Bjelland TW, Klepstad P, Haugen BO, et al. Effects of hypothermia on the disposition of morphine, midazolam, fentanyl, and propofol in intensive care unit patients. Drug Metab Dispos 2013; 41: 214-23.

11. Hostler D, Zhou J, Tortorici MA, et al. Mild hypothermia alters midazolam pharmacokinetics in normal healthy volunteers. Drug Metab Dispos 2010; 38: 781-88.
4. Chandran Mahaldar DA, Gadhinglajkar S, Sreedhar R. Sevoflurane requirement to maintain bispectral indexguided steady-state level of anesthesia during the

12. Schmidlin D, Hager P, Schmid ER. Monitoring level of sedation with bispectral EEG analysis: Comparison between hypothermic and normothermic cardiopulmonary bypass. Br J Anaesth 2001; 86: 779-86.

13. Chandran Mahaldar DA, Gadhinglajkar S, Sreedhar R. Sevoflurane requirement to maintain bispectral indexguided steady-state level of anesthesia during the rewarming phase of cardiopulmonary bypass with moderate hypothermia. J Cardiothorac Vasc Anesth 2013; 27: 59-62.

14. Wang $X$, Zhang J, Feng $K$, et al. The effect of hypothermia during cardiopulmonary bypass on three electro-encephalographic indices assessing analgesia and hypnosis during anesthesia: consciousness index, nociception index, and bispectral index. Perfusion. 2020; 35: $154-62$.

15. Miyazaki R, Hoka S. What is the predictor of the intraoperative body temperature in abdominal surgery? J Anesth 2019; 33: 67-73.

16. Nguyen NT, Fleming NW, Singh A, et al. Evaluation of core temperature during laparoscopic and open gastric bypass. Obes Surg 2001; 11: 570-75.

17. Moghadam MY, Shahi MN, Abadi BD, et al. Association Between Bispectral Index (BIS) Value and Postoperative Shivering in Patients Undergoing Orthopedic Surgery 2019; 15: 1166-9.

18. Chiang MH, Wu SC, HSU SW, et al. Bispectral Index and non-Bispectral Index anesthetic protocols on postoperative recovery outcomes. Minerva Anestesiologica 2018; 84: 216-28. 